\title{
Sien, hoor en ken: Basisteoretiese perspektiewe op geloofsopvoeding deur die' onderhouding van die Pasga. 'n Verkenning van Ou-Testamentiese gegewens
}

G. Breed en C.J.H. Venter

Dept. Diakoniologie en Missiologie

Potchefstroomse Universiteit vir $\mathrm{CHO}$

POTCHEFSTROOM

\begin{abstract}
See, hear and know: Basic-theoretical perspectives on instruction in faith by celebrating Passover. A survey of Old Testament data
\end{abstract}

In this article it is contended that God himself instructs his covenant people in a concrete and visible manner by revealing Himself to this people. Attention is paid to God as subject of instruction, the parents as subjects of instruction and the people of the covenant as subject of instruction. Furthermore, extensive attention is paid to the aim of instructing the children of the covenant by celebrating the Passover. In this respect the dimensions of seeing, hearing and knowing as perspectives of cardinal importance in instructing children are analysed. Finally, guidelines are given for the praxis of instructing children of the covenant in faith.

\section{Navorsingshipotese}

Hierdie artikel ondersoek bepaalde onderrigdimensies wat in die OuTestamentiese Pasgaviering saamvloei - onderrigdimensies wat relevant is vir geloofsopvoeding en nader ontgin behoort te word. Hierdie ontginning kan bydra tot die gesprek wat tans in Suid-Afrika gevoer word oor vernuwing in die kategese (Van Niekerk, 1994:55; Prins, 1993:81-93).

Meer spesifiek word in hierdie artikel stilgestaan by die vraag na "ruimer moontlikhede van kommunikasie" (Hanekom, 1994:111) as net menslike "taal". Watter rol kan die viering van bepaalde herdenkingsgeleenthede beklee in die geloofsonderrig van die kind? 
Gerber (1995:1) dui die invloed wat eksterne faktore (soos die viering van 'n godsdienstige fees) op die leerproses kan hê aan en sê dat geen leerproses binne 'n vakuum plaasvind nie en dat alle leer kontekstueel is. Die konteks waarin die leer plaasvind, beïnvloed die leerproses positief of negatief.

Beukes (1995:2) wys op die belangrikheid van 'n verskeidenheid wyses van onderrig as hy sê dat die taak wat God aan sy volk opdra om die kinders te onderrig, nie afgehandel kan word deur "outoritêre, amptelike, skoolse onderrig in 'n verskuilde hoekie slegs op Sondag" nie. Kategese word tans beskou as een deel van die didaktiese handelingsveld waardeur God se volk mekaar bedien (Firet, 1977:82). Kategese moet daarom deel wees van die totale geloofsopvoeding wat die kind in verskillende kontekste soos die ouerhuis, erediens en ander gemeentebyeenkomste ontvang (Breed, 1994:279, 280).

Die vraag onstaan dus hoeveel vandag tot die onderrig van die kind bygedra word wanneer 'n bepaalde konteks doelbewus geskep word met die oog op die onderrig van die gemeente. Waar die viering van die Pasga binne 'n doelbewus geskepte konteks plaasgevind het, kan daaruit moontlik relevante riglyne getrek word met die oog op die ondersoek van die navorsingshipotese.

In 'n poging om vernuwing in die kategese te bewerk en weg te beweeg van 'n bloot kognitiewe benadering, "is dit baie belangrik om steeds terug te gryp op dit wat in die $\mathrm{Ou}$ Testament opgeteken is oor die wyse waarop geloofsonderrig plaasgevind het" (Prins, 1993:1).

Vir die doel van hierdie artikel word die nagaan van die inhoud en betekenis van die Pasga beperk tot $\mathrm{Ou}$-Testamentiese gegewens. Hierdie fees het waarskynlik in die een of ander vorm onder Israel of ander volkere bestaan voordat 'n bepaalde gebeurtenis in die geskiedenis van Israel daaraan verbind is (De Vaux, 1976:3 e.v.). God gee egter deur sy optrede en opdragte 'n nuwe betekenis aan hierdie fees (Vriezen, 1974:278). Die Skrifgegewens word in hierdie artikel ondersoek binne die konteks waarin dit in die Woord van God geskryf staan. Daar word dus nie ingegaan op die verskillende teorieë (vgl. Houtman, 1989:139-156) in verband met die ontstaansgeskiedenis van die teks waarmee gewerk word nie.

\section{Die motivering van Eksodus 1-15 as ondersoek- materiaal}

Fretheim (1991:14) sê dat die kennis van God en sy selfopenbaring in die boek Eksodus besondere klem ontvang. Farao vra die vraag "Wie is Jahwe" en God sê dat die farao en die Egiptenaars $(7: 17 ; 8: 10,22 ; 9: 14,29 ; 11: 7 ; 14: 4,18)$ en Israel $(10: 2 ; 29: 46)$ sal weet wie Hy is. 
Binne die konteks van Eksodus 1-15 beskryf Eksodus 11:1-13:16 die instelling van die Pasga, die fees van die ongesuurde brood, die wyding van die eersgeborenes asook die aankondiging en inwerkingstelling van die tiende plaag. Vir die doel van hierdie artikel sal die Pasga, die fees van die ongesuurde brood en die wyding van die eersgeborenes, met die begrip Pasga as 'n eenheid aangedui word. In Eksodus 12:26 en 13:8, 9, 14, 15 ontvang die ouers opdrag om hulle kinders te onderrig in die betekenis van die Pasga. Wanneer gevra word na die onderrig deur die onderhouding van die Pasga as deel van geloofsopvoeding, word Eksodus 1-15 dus as toepaslike ondersoekmateriaal beskou.

\section{God onderrig sy volk konkreet en sigbaar}

\subsection{God vervul sy verbondsbelofte sigbaar}

In Eksodus 1:1-2:10 word verhaal hoe die Egiptenare Israel as bedreiging ervaar het omdat hulle 'n baie groot nasie geword het. Die nuwe koning van Egipte wat nie vir Josef geken het nie (vers 8), sê Israel die stryd aan (vers 10). Die plan wat hy beraam, bedreig Israel se bestaan as volk aangesien alle seuntjies wat gebore word, doodgemaak moet word. Die farao sê egter, sonder dat hy dit weet, nie alleen vir Israel nie, maar vir God die stryd aan - Israel se groei tot 'n groot nasie (vers 7,12 ) is immers die vervulling van God se belofte aan Abraham (Genesis 17:1-6).

Die vervulling van God se verbondsbeloftes het dus sigbaar geword. Farao se pogings om hierdie vervulling teen te staan, faal ook sigbaar. Die gelowige Israeliet kon in hierdie gebeure die vervulling van God se verbondsbeloftes sien en ervaar en sy kind onderrig deur sy aandag op hierdie konkrete gebeure te vestig. God gaan egter in die Pasga aan die ouers 'n hulpmiddel gee om hulle kinders hierdie dinge te kan onderrig - ook in die toekoms wanneer die konkrete gebeure nie meer voor oë is nie. Die bitter brood van die Pasga maak onderrig oor die sin van lyding moontlik. Die viering van die Pasga konkretiseer die onderrig aangaande verlossing van die dood langs die weg van geloofsgehoorsaamheid.

\subsection{God illustreer konkreet dat hy sy volk hoor, aan hulle dink, hulle sien en ken}

In Eksodus 2:23-25 word God se reaksie op die volk se verdrukking beskryf in vier opeenvolgende sinne waarin die Naam van God (Elohim) telkens herhaal word (Fretheim, 1991:48):

* God het die klag van die volk gehoor.

* God het gedink aan sy verbond met Abraham, Isak en Jakob. 
* God het die kinders van Israel aangesien.

* God het geken (sonder voorwerp).

God se reaksie op dit wat Hy sien en hoor, gaan uiteindelik uitloop op die viering van die Pasga. Hierdie eerste Pasga sal dan gevier word in afwagting van die finale slag wat God teen die farao gaan lewer. Wanneer God by die huise verbygaan en die bloed van die paaslam aan die deurkosyne sien, sal $\mathrm{Hy}$ dink aan sy belofte wat Hy gekoppel het aan die bloed. Hy sal hulle ken as sy volk wat sy belofte geglo het en daarom die bloed aan die deurkosyne gesmeer het. Die gekerm sal daarom net by die Egiptenare gehoor word en nie meer by Israel nie. By Israel is daar nou vreugde en spoedig sal die lied van oorwinning by hulle gehoor word (Eksodus 15).

In die viering van die Pasga sou die kind dus konkreet leer wat dit beteken dat God sy volk hoor, aan sy beloftes dink, hulle aansien en hulle ken.

\subsection{God openbaar homself sigbaar aan sy volk}

In God se openbaring aan en gesprek met Moses in Eksodus 3:1-17 speel die begrippe sien, hoor, ken en dink'n belangrike rol:

* Moses sien die bos wat brand, hy gaan nader om die verskynsel te bekyk. Wanneer hy agterkom dat dit God is wat aan hom verskyn, bedek hy sy gesig want hy wou God nie aanskou nie.

* Moses hoor die stem van God wat met hom praat, maar hy wil nie gehoorsaam luister na die opdragte nie.

* God openbaar Homself aan Moses sodat hy God kan ken as die God van sy vader, die God van Abraham, Isak en Jakob. Hy moet God ook ken as die God wat sy volk se ellende sien en hoor en hulle smarte ken en wat daarom neergedaal het om hulle te verlos en na die beloofde land te lei.

* Wanneer hy sy opdrag gaan uitvoer, kan hy dink aan dit wat God aan hom gesê het en daaruit krag put.

Eksodus 4 begin (vers 1) met Moses se twyfel of die volk hom gaan glo dat God aan hom verskyn het en of hulle na sy stem sal luister (sal hoor). Eksodus 4 sluit af (vers 31) met die volk wat glo en in aanbidding neerbuig voor die Here. Die res van die hoofstuk handel oor Moses en die volk se reaksie op God se genade wat Hy op grond van sy verbondsbeloftes bewys. In vers $2-9$ gee die Here aan Moses tekens sodat die volk ook kan sien dat die Here aan hom verskyn het. Wanneer Moses beswaar maak dat hy me 'n man van woorde is nie, antwoord die Here dat dit $\mathrm{Hy}$ is wat sorg dat die boodskap reg oorgedra 
(vers 11a) word, asook dat dit reg ontvang word (vers 11b). Op sy verdere beswaar gee God vir Aäron opdrag om namens Moses te praat, maar God lê ook klem daarop dat hy die staf waarmee die tekens gedoen moet word, moet saamneem (vers 17, vgl. ook vers 20). Ook op sy terugreis sê God weer aan Moses om die wonders voor die farao te doen (vers 21).

Uit die voorafgaande is dit duidelik dat God sy volk deur sy woord wil onderrig, maar dat Hy, om hulle tegemoet te kom, ook sterk klem lê op onderrig deur tekens.

\section{Subjek van die onderrig}

Uit die voorafgaande ondersoek het dit duidelik geword dat die kind in Israel op 'n sigbare, konkrete wyse onderrig is deur die viering van die Pasga. Daar sal nou gevra word na die subjek wat hierdie onderrig aan die kind oordra.

\subsection{God as subjek van die onderrig}

God is die primêre subjek van die onderrig deur die viering van die Pasga. Die hele fees ontvang sy betekenis deur God se woord en daad.

God se verlossingsdade vorm die inhoud van die fees - sonder hierdie daad van God sou die fees geen sin gehad het nie. Die fees is egter nie 'n herdenking van die historiese feite nie, maar is 'n herdenking van die getrouheid van God aan sy verbondsbeloftes en sy liefde wat Hy daardeur aan Israel bewys het. Verder herdenk die fees ook die band wat God deur sy optrede met Israel gevestig het, naamlik dat Hy die feit dat hulle sy volk is, konkreet sigbaar laat word het. God is dus subjek van die onderrig daarin dat Hy die inhoud van die onderrig verskaf het deur sy dade.

God is ook subjek van die onderrig in die viering van die Pasga deur sy Woord. God gee aan Moses opdragte aangaande die viering van die Pasga. Deur sy opdragte verbind God 'n sekere betekenis aan elke deel van die fees. Deur sy Woord verskaf God dus die middele waarmee die onderrig moet plaasvind. God gee ook opdrag dat die kinders deur die viering van die Pasga onderrig moet word (Eksodus 12:14, 26, 27, 42; 13:8, 9, 14-16). God is dus subjek van die onderrig in die Pasga daarin dat Hy die simboliese betekenis van die Pasga vasstel en dat Hy opdrag gee om deur die Pasga te onderrig.

God is egter ook tydens die viering van die Pasga subjek van die onderrig op grond van dit wat tydens die fees gedoen word. Die verlossing het vir elke Israelitiese gesin 'n werklikheid geword deur die gehoorsame viering van die Pasga. In hierdie viering het God Homself geopenbaar en werk Hy deur die openbaring in die deelnemers se harte. Deur die viering van die Pasga kon God mense tot geloof bring. Wie nie Pasga gevier het nie, het gedeel in die lot van 
God se vyand en was nie deel van die volk van God nie omdat hulle die getuienis van die God nie aanvaar het nie. Die verlossing wat God bewerk het, kan dus nie losgemaak word van die viering van die Pasga nie. God bewerk verlossing ook deur die viering van die Pasga. Telkens wanneer die Pasga weer gevier word, wanneer die gebeure van die eerste Pasga opnuut beleef word, word die verlossing moontlik vir elkeen wat daaraan deelneem deur die kragtige werking van God. Wie glo wat deur die Pasga onderrig word, word uitgelei uit die slawehuis van die sonde, word waarlik deel van God se verloste volk. Fretheim (1991:139) stel dit so:

As such, it is passover which is act of God; in and through the celebration of the passover God works salvation initially, and ever anew, in the lives of the participants, [re]constituting them as the redeemed exodus community.

Hierdie vernuwende werking vind plaas deur God se Gees.

God is dus ook die finale subjek van die onderrig deur sy kragtige werking in die harte van deelnemers aan die Pasga sodat hulle die onderrig sal glo en daarvolgens sal leef.

\subsection{Die ouer as subjek van die onderrig}

Die voorskrifte wat God gee aangaande die viering van die Pasga, gee daaraan grotendeels die karakter van 'n familiefees (vergelyk Eksodus 12:3 "Op die tiende van hierdie maand moet elkeen 'n lam neem, volgens die families, 'n lam vir 'n huisgesin"). Die aksies wat die voorbereiding van die Pasga begelei, het grootliks binne gesinsverband plaasgevind: die lam wat van die tiende van die maand in bewaring gehou moet word, die voorbereiding van die ongesuurde brood en die kruie, die bloed van die lam aan die deurkosyne, die gaarmaak van die lam, die feit dat die lam deur die gesin opgeëet moes word, die gereedmaak vir die vertrek (12:11), die eet van die ongesuurde brood vir sewe dae lank het alles binne gesinsverband plaasgevind. Die ouer was dus van alle mense in die gunstigste posisie om deur sy nakoming van God se opdragte die kind te onderrig. Die kind sou die ouer se geloof en gehoorsaamheid in die voorbereiding en viering van die Pasga kon sien. Die ouer ontvang egter ook opdrag om die betekenis van die viering van die Pasga aan die kinders te verduidelik (Eksodus 12:14, 26, 27, 42; 13:8, 9, 14-16). Die Pasga moes van geslag tot geslag gevier word as 'n ewige instelling (Eksodus 12:14, 42); hierin speel die onderrig wat ouers aan kinders gee 'n kardinale rol. Wanneer ouers dit nie aan kinders leer nie, sal die kinders nie meer dink aan Jahwe se verlossingsdade nie en sal hulle Hom ook nie meer ken nie (Van Rooy, 1990:7).

Die wyding van die eersgeborenes van Israel aan die Here deur 'n offer spreek van die ouer se taak om die kind aan God te bind deur hom te begelei om God 
te ken en te dien. Houtman (1989:189) sê aangaande die wyding van die eersgeborenes dat dit die betekenis dra dat "heel het leven in het teken staan van de bij de uittocht bewezen weldaden".

Ouers is dus die primêre menslike subjek van die onderrig deur die viering van die Pasga. Hulle onderrig die kind deur die wyse waarop hulle die Pasga vier en deur hul mondelinge onderrig aangaande die betekenis van die Pasga.

\subsection{Die volk as subjek van die onderrig}

Alhoewel die hoofklem van die viering van die Pasga op die huisgesin val, speel die samebinding van die volk ook 'n belangrike rol daarin. In die voorskrifte wat God aan Moses gee, lê Hy klem daarop dat die volk die Pasga moet vier (Eksodus 12:3,6,19, 47). Iemand wat nie die voorskrifte nakom nie, verloor die voorreg om deel te wees van die volk van God. In Eksodus 12:6 is die voorskrif dat die hele vergadering (ערת) van die gemeente (עדול) van Israel op dieselfde tyd die paaslam moet slag. Uit Eksodus 12 is dit nie bo alle twyfel duidelik of elkeen die lam op daardie tyd by sy eie huis moes slag nie (vgl. Houtman, 1989:162, 163) en of die hele volk saam moes vergader en daar saam slag nie (Fensham, 1977:50). Die opstapeling van die begrippe כל, ערת שרת maak dit waarskynlik dat hier sprake is van 'n volksvergadering waartydens elkeen sy lam geslag het (Oosthuizen, 1989:195). Ook die feit dat in Deuteronomium 16:2 'n sentrale plek aangewys word waar die paaslam geslag moet word, dui op 'n vergadering van die volk tydens die slag van die lam. Die lam kon daama in gesinsverband gaargemaak en geëet word (McConville, 1984:107-110). Oosthuizen (1989:195) sê met verwysing na die

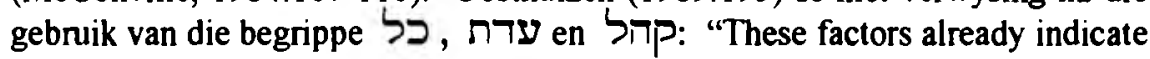
that, with the narration of God's decisive liberating act at its core, the Passover liturgy shapes Israel's identity as the community of God".

Die kind kon die vergadering van die gemeente aanskou het terwyl hulle saam (ten opsigte van tyd en of plek) die paaslam slag. Die kind ontvang deur hierdie gesamentlike handeling van die volk onderrig in gehoorsaamheid aan God se voorskrifte. Hy ervaar daarmee ook die eenheid van die volk van God en in sy hart word die kennis bevestig insake die volgende aspekte:

* God was getrou aan sy belofte aan Abraham.

* God het Abraham se nageslag grootliks vermeerder.

* God het aan hulle die verlossing van die magte wat hulle wou vernietig, geskenk.

* God het Israel inderdaad tot 'n volk gemaak - 'n volk waarvan die kind deel was. 
Hieruit is dit duidelik dat die volk deur die viering van die Pasga gefunksioneer het as subjek van die onderrig aan die kind.

\section{Die doel van onderrig aan die kind wat deur deel- name aan die Pasga bereik kan word}

\subsection{Begeleiding tot verering van die Here deur deelname aan die Pasga}

In Eksodus 12:14 word die Pasga 'n fees vir Jahwe genoem. Die betekenis van die uitdrukking "vir Jahwe" word deur Houtman (1989:172) weergegee as "ter ere van Jahwe" (vgl. ook die 1933 en 1983 Afrikaanse vertaling van die Bybel). Baumgartner (1958:462-466) dui onder andere die volgende betekenismoontlikhede van die voorsetsel ? aan:

* Dit dui die rigting aan waarin iets beweeg,

* dit dui die voorwerp aan warop vertroue geplaas word,

* dit dui die doelwit van 'n aksie aan,

* dit dui aan dat iets ter wille van iemand gedoen word.

Op grond van bogenoemde betekenismoontlikhede blyk dat die vertaling "'n fees ter ere van Jahwe", geregverdig is. Die fees van die Pasga is toegespits op Jahwe, $\mathrm{Hy}$ is die einddoel van die hele fees, want dit word ter wille van Hom gevier.

Die opdrag van Eksodus 12:14 lui dat hierdie fees in die geslagte as 'n ewige insetting gevier moet word. Hierdie opdrag hou dus in dat die kinders onderrig moes word om die fees te vier. Die doel van hierdie onderrig was dan om die kind te begelei om die Pasga tot eer van die Here te vier.

\subsection{Begeleiding tot diensbaarheid aan God deur deelname aan die Pasga}

Die begrip עבר speel 'n baie belangrike rol in die geskiedenis van Israel soos dit in Eksodus 1-15 verhaal word. Reeds in Eksodus I word Israel se lyding in Egipte met hierdie begrip beskryf. Dié begrip word vyf keer in vers 13,14 gebruik en 'n verdere twee keer in vers 23. In hoofstuk 5 word עבד gebruik om die verswarende diens te beskryf wat die farao op die volk lê na sy eerste gesprek met Moses. In hoofstuk 6 belowe God om Israel van hierdie harde diens te verlos. Dieselfde begrip word egter herhaaldelik gebruik om Israel se diens aan die Here te beskryf (Eksodus $3: 12 ; 4: 23 ; 7: 16,26 ; 8: 16 ; 9: 1,13 ; 10: 3$, $7,8,11,24,26 ; 12: 25,26,31)$. In 'n seker sin kan gesê word dat dit in hierdie 
gebeure nie in die eerste plek gaan oor vryheid en slawemy nie, maar oor die identiteit van die een aan wie Israel diensbaar is.

In Eksodus 12:25, 26 word die viering van die Pasga met die begrip עברה getipeer. Die Pasga is deel van die volk se diensbaarheid aan die God wat hulle bevry het van die diensbaarheid aan die vernietigende mag van die farao. Wanneer hulle die Pasga vier, herdenk hulle God in sy verlossingsdade aan hulle en sodoende dien hulle Hom. Oosthuizen (1989:30) sê aangaande Eksodus 12:24, 25: "Once again ... the point is made that God's purpose does not primarily lie in liberation, but in the creation of a worshipping community". Dit is hier ook van belang om die tweërlei betekenis wat die begrip עבר ten opsigte van die diens aan God het, in ag te neem. Die begrip kan naamlik verwys na die diens wat aan God bewys word deur die kultus en ook na die algemene erkenning van God se koningskap (Plastaras, 1976:32).

Wanneer die kind deur die viering van die Pasga onderrig word, sal die doel van hierdie onderrig dus onder andere moet wees om hom te begelei tot deelname aan die volk se diensbaarheid aan God. Hierdie onderrig sal insluit dat die kind God sal dien deur die viering van die Pasga. Die viering van die Pasga is daarom ' $n$ simboliese verklaring van bereidheid om diensbaar te wees in sy hele lewe.

\subsection{Herbelewing van God se verlossingsdade as doel van die viering van die Pasga}

In Eksodus 12:14 word die Pasga met drie verskillende begrippe beskryf. Dit is 'n gedenkdag (זכרון), 'n fees (חר) en 'n ewige insetting. Die eerste begrip is van belang vir die doeleindes van hierdie artikel. Die begrip זכרון druk meer uit as bloot dat daar weer aan sekere gebeure gedink moet word. Die begrip het eerder die betekenis van heraanbieding met die oog op die herbelewing van gebeure van die verlede (Plastaras, 1966:146). Elkeen wat deelneem aan die Pasga moet weer die gebeure in Egipte beleef asof hy deel is daarvan. Hy moet God opnuut leer ken uit sy verlossingsdade in Egipte en so opnuut leer verstaan wat dit beteken om deel te wees van God se volk. Die verlossingskrag van God, soos dit na vore gekom het in die oorspronklike gebeure, word weer beskikbaar gestel aan die gemeente binne die konteks van die godsdiens. Wie deur die viering van die Pasga tot geloof kom dat God sy volk kan verlos, kry deel aan die verlossing en word deel van God se verloste volk.

Die kind in Israel moes dus deur sy deelname aan die Pasga leer verstaan wat daar in Egipte gebeur het. Hy moes God leer ken soos Hy Hom in Egipte aan Israel geopenbaar het. So sou die kind in sy konkrete situasie op God kon vertrou om hom te verlos van die sonde en in sy hart bereid wees om hom in diensbaarheid aan God te onderwerp. 


\subsection{Deelname aan die Pasga moes die kind begelei tot gehoorsaamheid aan die wet van God}

In Eksodus 13:8, 9 ontvang die ouers opdrag van die Here om die betekenis van die Pasga (in die besonder die ongesuurde brood) aan die kinders te verduidelik. Die verduideliking van die betekenis van die fees staan sentraal in die viering van die fees. Die onderrig in die betekenis van die fees is egter nie doel op sigself nie; die viering van die fees is 'n hulpniddel (teken) sodat God se wet vir die feesganger aktueel (in sy mond) sal bly.

Die Ou-Testamentiese kind het God leer ken in en deur die viering van die fees; hy het hom deel gevoel van God se verloste volk sodat hy aan God diensbaar wou leef; daarom het hy nou na die wet van God gevra.

Die doel van die onderrig deur die viering van die Pasga was dus om die kind daartoe te bring om uit liefde en dankbaarheid vir God se verlossing gehoorsaam aan die wet te leef. Hierdie doel impliseer nie 'n slaafse gehoorsaamheid nie, maar 'n gehoorsaamheid wat voortvloei uit begrip, 'n gehoorsaamheid wat steeds groei vanuit 'n voordurende gesprek oor die aktuele betekenis van die wet van God.

\subsection{Deur deelname aan die Pasga moes die kind leer om die vreugde van die verlossing te beleef}

$\mathrm{Na}$ die finale nederlaag van die farao en sy manne in die Rooisee, sing Moses en die hele Israel ' $n$ lied tot eer van die Here. Mirjam lei die vroue in koordanse met tamboeryne terwyl hulle sing (Eksodus 15). Dat hierdie feesvreugde 'n wesenlike deel van die viering van die Pasga en die sewe dae daarna geword het, is duidelik uit 2 Kronieke 30:21, 22. Hier word gesê dat die fees met groot vreugde gevier is en dat die "Leviete en die priesters die Here dag vir dag geprys het met kragtige instrumente tot eer van die Here" en dat die volk "die Here, die God van hulle vaders, geloof het" vir die sewe dae. So groot was die vreugde dat hulle besluit het om die fees met sewe dae te verleng ( 2 Kronieke 30:23), en hierdie sewe dae is ook met blydskap gevier.

Ook in Esra 6:22 word gesê dat die fees met blydskap gevier is. Die rede vir die blydskap word met die volgende woorde aangedui: “... want die Here hulle God het hulle verbly en die hart van die koning van Assirië na hulle omgewend, om hulle hande te versterk in die werk aan die huis van God, die God van Israel". Die fees was dus 'n fees van vreugde oor God se groot dade tot verlossing van Israel en tot diensbaarheid aan God. Wat hier van besondere belang is, is dat die blydskap in die viering van die Pasga nog steeds gaan oor God se sterke hand waarmee Hy sy volk bevry, maar hier het 'n belangrike oorgang plaasgevind. Die volk verbly hulle oor God se redding in hulle 
situasie, hier en nou. Die vreugde oor God se verlossing in Egipte gaan oor in vreugde oor God se verlossing nou - so word God in die viering van die Pasga leer ken as dié God wat verlos.

Die kind kon deur sy meedoen aan hierdie feesvreugde die vreugde in God sy eie maak. Hy kon sodoende deel voel van God se volk en ook ervaar dat hy deel is van die verlossing wat God bewerk. Die doel van die onderrig was dus om die kind die vreugde van die verlossing te laat beleef - ook oor sy eie verlossing in sy konkrete persoonlike situasie.

\section{Die wyse van onderrig deur die viering van die Pasga}

\subsection{Onderrig vind plaas deur deelname aan die fees}

Aangesien die fees hoofsaaklik ' $n$ gesinsfees was, kon die kinders by elke faset van die fees betrokke wees. Hulle kon sien hoedat 'n geskikte lam sonder gebrek uitgesoek word. Gedurende die tydperk vanaf die tiende tot die veertiende van die maand, Abib, kon hulle daagliks die lam sien, afgesonder om as paasoffer te dien. Wanneer die volk almal tegelyk teen sononder die offer slag, kon hy dit saam met sy ouers beleef. So ook die smeer van die bloed aan die deurkosyne, die gaarmaak van die vleis en die voorbereiding van die ongesuurde brood. Die ete saam met sy gesin sou die geleentheid skep om elke jaar opnuut te vra na die betekenis van dit alles. Die sewe dae daama waarin ongesuurde brood geëet is en die offer van die eersgeborenes gebring is, sou die onderrig wat die kind ontvang het, weer en weer bevestig - God het Israel met 'n sterke arm uit Egipte bevry om hulle as sy eiendom aan Hom te wy. Die kind kon beleef dat hy deel daaraan het so seker as wat hy gelowig deel het aan die fees. So is die kind onderrig deur praktiese meedoen en meeleef.

\subsection{Onderrig deur voorbeeld}

Aangesien die kind op genoemde wyse betrokke is by die voorbereiding vir en die viering van die fees, leer hy ook deur die voorbeeld van sy ouers. Die kind neem die gesindheid waarmee die ouers die fees vier, waar. So word hy deur godvresende ouers onderrig in geloofsgehoorsaamheid en volle toewyding aan God. Hulle voorbeeld was die instrument waardeur die kind onderrig ontvang het.

\subsection{Mondelinge onderrig}

Die praktiese meedoen en meeleef en die gepaardgaande waarneming van die ouers se voorbeeld het die kind gestimuleer om te vra na die betekenis van die gebeure. God dra egter aan die ouer op om die betekenis van die fees, gevraagd 
(Eksodus 12:26; 13:14) of ongevraagd (Eksodus 13:8), aan die kinders duidelik te maak.

Mondelinge onderrig deur vraag en antwoord of spontaan van die ouer se kant is dus ' $n$ noodsaaklike wyse van onderrig.

\subsection{Onderrig deur sang en lied (feesvreugde)}

$\mathrm{Na}$ die oorwinning oor die farao sing Moses en die Israeliete 'n lied (Eksodus 15). Die volgende sake val op in hierdie lied:

* Dit is primêr 'n loflied tot eer van God.

* Dit is 'n lied wat voortvloei uit spontane dankbaarheid vir die oorwinning en verlossing.

* Die persoonlike reaksie van die gelowiges word in die eerste persoon enkelvoud verwoord. Alhoewel die volk dus die lied saam gesing het, het elke gelowige persoonlik sy lof tot God uitgespreek.

* Daar is 'n noue verbinding tussen die herdenking van die gebeure en die verheerliking van God. Vanuit die herroeping van dit wat gebeur het, vloei die drang om God te loof (vgl. Fretheim, 1991:134, 161-165). Indien hierdie lied in later geslagte gesing sou word, sou dit die kinders tegelyk onderrig het aangaande die feite van die geskiedenis en hulle ook begelei het om God te loof. Daar is dus geen skeiding tussen onderrig en die verheerliking (worship) van God nie.

* Die vreugde en lof aan God word ook deur liggaamstaal uitgedruk. Die vroue, met Mirjam as leier, speel op die tamboeryn, loop en dans en sing van God se groot dade (vgl. Fretheim, 1991:161). Die kinders sou baie sterk aansluiting kon vind by hierdie sigbare, konkrete uiting van vreugde.

Ook die viering van die Pasga (veral die sewe dae waartydens ongesuurde brood geëet is) het gepaard gegaan met sang onder begeleiding van musiekinstrumente. Op hierdie wyse is die vreugde oor die verlossing wat God bewerk, uitgedruk (vgl. 5.5.6). Die kind het as deel van die volk hieraan meegedoen, of het dit gehoor en gesien. Gaandeweg kon die kind self die liedere leer ken, hy het ook geleer om sy vreugde in God openlik te wys.

Die kind is dus ook by wyse van sang en lied (feesvreugde) onderrig. 
7. Konklusie ten opsigte van die onderrig deur die viering van die Pasga

* Deur die viering van die Pasga is die kind op 'n konkrete wyse onderrig binne 'n konteks wat doelbewus geskep is om leer te bevorder.

* Deur die viering van die Pasga word God se optrede op grond van sy verbondsbeloftes herdenk. Die kind is begelei om verskeie aspekte van die verbond te begryp deur dit wat hy gesien en gehoor het.

* God verskaf deur sy dade, Woord en Gees, die inhoud, stukrag en vrug van die onderrig deur die viering van die Pasga. God is dus die primêre subjek van die onderrig.

* Die ouer is as mens die hoofsubjek van die onderrig binne die milieu van die gesin, maar altyd in verbondenheid met die volk.

* Die volk as eenheid tree ook op as subjek van die onderrig in hulle getrouheid aan God se voorskrifte en hulle vreugde oor God se verlossing.

* Die doel van die onderrig is dat die kind die verlossing wat God bewerk as werklikheid ervaar, homself as deel van God se volk op 'n simboliese, maar konkrete wyse ten volle aan God wy, en so met vreugde tot eer van God leef.

* Die kind is gedurende die viering van die Pasga onderrig by wyse van:

- deelname aan die fees,

- die voorbeeld van ouers en die hele volk,

- mondelinge onderrig,

- $\quad$ sang en lied.

8. Perspektiewe vir die hedendaagse onderrig van die kind

* $\quad$ Onderrig binne 'n doelbewus geskepte konteks, soos die viering van 'n bepaalde fees, kan 'n belangrike verruiming bring in die metodiek van geloofsopvoeding.

* God wil die kennis aangaande sy dade lewend hou onder sy volk deur die feeste wat Hy sy volk gegee het om te vier. Die gebruik van die sakramente en die herdenking van mylpale in die lewe van die NuweTestamentiese volk (byvoorbeeld die geboorte, kruisiging, opstanding, hemelvaart van Jesus en die uitstorting van die Heilige Gees) kan dien as kontekste waarin die kind onderrig kan word sodat hy self kan sien, 
hoor en ken (geloofskennis). Deur hierdie onderrig kan hy as totale mens aangespreek word deur sy verstand, emosies en wil te betrek.

* Bo en behalwe die oordra van kennis is die viering van die fees ook daarop gemik om die kind die verlossingsdade van God as 'n werklikheid te laat ervaar. Die kind moet betrokke gemaak word by byvoorbeeld die erediens, doop en Nagmaal, sodat hy daardeur God as 'n werklikheid kan beleef. Betrokkenheid by die erediens kan byvoorbeeld bewerk word deur in die voorafgaande week die kern van die preek aan die kind op 'n bevatlike wyse oor te dra. Tydens die preek in die erediens kan dan na hierdie onderrig verwys word. Daar kan ook op die voorafgaande Sondag 'n bepaalde psalmvers aan die ouers deurgegee word om aan die kind te leer en hierdie vers word dan in die erediens gesing. Tydens die doop of Nagmaal kan die kern van die formulier op ' $n$ baie bevatlike wyse aan die kinders oorgedra word net voor die bediening van die sakrament.

* Die gesin sal opnuut (vanuit die simboliese herdenking van God se dade), prakties deel van die onderrig gemaak moet word. Ouers kan byvoorbeeld deur gereelde Bybelstudie op voorafgaande Sondae begelei word om in die week hulle kinders voor te berei vir die sakramentsbediening of herinneringsfees. Aandrang op betrokkenheid van ouers by die voorbereiding vir kategese is ook baie belangrik.

* Die feit dat sowel die gesin as die gemeente as geheel 'n noodsaaklike rol te vertolk het in die onderrig sal verdiskonteer moet word. Die viering van herinneringsfeeste kan so ingerig word dat hierdie wyse van onderrig kan plaasvind. So kan byvoorbeeld met die gemeente gereël word dat elke gesin vroeg op Kersdag die geboortegeskiedenis van Christus saam lees. Daarna vertrek die gesin na die kerk waar hulle saam met die gemeente deel het aan 'n program van sang, onderrig uit die Woord en gebed. In hierdie program kan spesifieke geleentheid aan kinders gegee word om saam te sing of in 'n spreekkoor op te tree.

Kleingroepe kan hierin ook 'n belangrike rol vertolk. In 'n kleingroep, bestaande uit ' $n$ paar gesinne, kan die kind geleentheid gegee word om vrae te vra, sy eie gedagtes oor te dra en homself deel te voel van God se volk.

Die praktiese uitvoering van die onderrig deur feesvreugde, waarin sang en lied 'n groot rol speel in die lewe van die Nuwe- Testamentiese volk van God sal nader uitgewerk moet word. Gereelde geleenthede waarop God geloof word deur sang, die gemeente saam eet en hulle so 
in God verbly, kan geskep word. Telkens moet daar sorg gedra word dat die kinders deelneem en begryp waaroor alles gaan. Daar moet dus sorg gedra word dat kinders soveel as moontlik psalms ken, sodat hulle kan saamsing.

* Dit is dus duidelik dat die onderrig deur die viering van herdenkingsgeleenthede (soos deur God gegee), 'n noodsaaklike en unieke dimensie van die verbondsonderrig uitmaak.

\section{Bronnelys}

BAUMGARTNER, W. 1958. Lexicon in Veteris Testamenti Libros. Leiden : Brill.

BEUKES, M.J. DU P. 1995. Kategetiekteorieë met die oog op vernuwing. Ongepubliseerde referaat gelewer tydens die byeenkoms van die Werkgemeenskap vir Praktiese Teologie, Bloemfontein.

BREED, G. 1994. Kategese en geloofsopvoeding. Potchefstroom : PU vir CHO. (Th.D. proefskrif.)

DE VAUX, R. 1976. Ancient Israel. Its life and institutions. Translated by J. McHug. London : Darton, Longman \& Todd.

FENSHAM, F.C. 1977. Exodus. De prediking van het Oude Testament. Nijkerk : Callenbach.

FIRET, J. 1977. Het agogisch moment in het pastoraal optreden. Kampen : Kok.

FRETHEIM, T.E. 1991. Exodus. Interpretation. A Bible commentary for teaching and preaching. Louisville: John Knox Press.

GERBER, J.J. 1995. Leer en die kontekste van leer - 'n verkenning binne die raamwerk van geloofsvorming. Ongepubliseersde referaat gelewer tydens 'n byeenkoms van die Werkgemeenskap vir Praktiese Teologie, Bloemfontein.

HANEKOM, B. 1994. Ritueel en simbool as kommunikasiemedia. (In Van Rensburg G. \& Hendriks J. reds. Vernuwing in jeugbediening: gemeentes aan die woord. Pretoria : Engedi. p. 111-118.)

HOUTMAN, C. 1989. Exodus II. Commentaar op het Oude Testament. Kampen : Kok.

McCONVILLE, J.G. 1984. Law and theology in Deuteronomy. Sheffield : JSOT Press.

OOSTHUIZEN, M.J. 1989. The God of the exodus. A study of characterisation in Exodus 1-12. Pretoria : Unisa. (D. Th. proefskrif.)

PRINS, J.M.G. 1993. Ou-Testamentiese riglyne vir die kategese. Acta Theologica, 13(2):1-17.

PLASTARAS, J. 1966. The God of Exodus. The theology of the Exodus narratives. Milwaukee : Bruce. 
VAN NIEKERK, D.L. 1994. 'n Hermeneutiese kategesemodel. (In Van Rensburg G. \& Hendriks J. reds. Vernuwing in jeugbediening: gemeentes aan die woord. Pretoria : Engedi. p. 55-65.)

VAN ROOY, H.F. 1990. Die Pasga en sy boodskap in die tyd van die Ou Testament. Koers, 55(1):6-16.

VRIEZEN, Th. C. 1974. Hooflijnen der theologie van het Oude Testament. Wageningen : Veenman. 